http://jmscr.igmpublication.org/home/

ISSN (e)-2347-176x ISSN (p) 2455-0450

crossref DOI: https://dx.doi.org/10.18535/jmscr/v7i8.94

\title{
Development of Articulation among Assamese Speaking Children
}

\author{
Author
}

\author{
Lanu W. Aimol
}

\begin{abstract}
The present study is to develop a formal test of articulation of speech sounds in Assamese for the purpose of evaluation of articulation errors in Assamese speaking children and help them in management of language production errors among preschool and school going children.
\end{abstract}

\section{Introduction}

The study is an attempt at evaluating the development of the skill of production and use of speech sounds among Assamese speaking children. The term language disability relates to any child whose ability to use language is sufficiently underdeveloped or impaired as to require special treatment or teaching. The study encompasses the articulation of speech sounds of the Assamese speaking children.

The objective of the present study is to develop a formal test of articulation of speech sounds in Assamese for the purpose of evaluation of articulation in Children so as to help in assessment and management of language production errors among preschool and school going children with oral language problem.

About 240 children in the age range of 2 to 8 years were selected from five schools and tested to obtain norms for the acquisition of Assamese Speech Sound in and around Guwahati in the District of Kamrup. The age range of 2 to 8 years was divided into 6 sub-groups with one year interval as 2-3, 3-4, 4-5, 5-6, 6-7 and 7-8. Each sub-group had 40 children, comprising of both boys and girls. A total of 240 children were tested.
About 89 picturable words were given to "familiarity raters" out of which the highly familiar picturable words representing vowels and consonants in Assamese were selected for the test. 8 vowels including 7 dipthongs were selected and 29 pictured words were constructed for them. 21 consonants were considered and 60 pictured words were constructed to test them in a child. For each selected phonemes in Assamese, pictured words were constructed for three positions (initial, medial and final position). Whenever it was not possible then a word was selected which was used as ' repeat after me'. The test was made in a form of a booklet. The sounds $/(\mathrm{w}) /, / \mathrm{j} /$ in $/ \mathrm{zoja} /=\mathrm{a}$ name, /w/ in /paws/=/you get/, / iu/ in /ziu/ =/soul/, /ei/ in / zei/ = / pronoun/, /ov/ in/zov/ =wheat and $/ \mathrm{a} \sigma / \mathrm{in} / \mathrm{z}$ av $/=/ \mathrm{a}$ kind of tree /were omitted considering their minimal frequency of occurrence and availability of picture able words.

\section{Finding and Conclusion}

A test was carried out on 240 Assamese speaking normal children in the age group of 2 to 8 years. A statistical analysis was done from the collected data and the following conclusion had been drawn: There is an age related change in the 
articulation score of normal children. Therefore in younger children it is found that as age increase there is corresponding increase in the acquisition of phonemes. $67.5 \%$ children of the age group 2-3 produce the speech sounds / phonemes correctly. The pass percentage of children above $3-4$ is $100 \%$. That means most of the phonemes are acquired around 4 years of age. The mean articulation scores of female children has been found significantly different from that of the male children. Female score is higher than male. In early life of children it is thought that brain maturation starts early in girls than boys. Similar results have been reported in some other Indian languages by different investigators studied so far. With the $90 \%$ criterion adopted for development of a sound in the present study, it has been found that all the speech sounds have already been acquired by the 3-4 years old children.

$67.5 \%$ children of the age group 2-3 produce the phonemes correctly. The pass percentage of children above $3-4$ is $100 \%$ as shown in the Table-I. That means most of the phonemes are acquired around 4 years of age. $32.5 \%$ of children in the age group 2-3 years have not acquired the phonemes $/ \mathrm{ph} /, / \mathrm{z} /, / \mathrm{s} /, / \mathrm{y} / \& / \mathrm{r} /$ as maturation of brain specially neuromuscular coordination is yet to be ready. Among the speech sounds $/ \mathrm{y} / \& / \mathrm{r} /$ are developed later and these are acquired around 4 years of age.

As per the criteria adopted for acquisition of a phoneme in the present study it is concluded that by and large all the speech sounds had already been acquired by 4 years old children.

The mean articulation scores of female children has been found significantly different from that of the male children. Female score is higher than male. In early life of children it is thought that brain maturation starts early in girls than boys. Similar results have been reported in some other Indian languages by different investigators studied so far.
Table-I: Phonological acquisition of normal children

\begin{tabular}{|l|c|}
\hline Age group & Percentage \\
\hline $2-3$ yrs & 67.5 \\
\hline $3-4$ yrs & $100 \%$ \\
\hline $4-5 y r s$ & $100 \%$ \\
\hline $5-6$ yrs & $100 \%$ \\
\hline $6-7$ yrs & $100 \%$ \\
\hline $7-8$ yrs & $100 \%$ \\
\hline
\end{tabular}

A child having Articulation problems after 4 years will be considered a genuine disorder and be trained so that such children can communicate and learn normally in the class.

\section{References}

1. Bhattacharya, K. (1988). Bengali Phonetic Reader. Central Institute of Indian Languages, Mysore.

2. Bloom, L. \& Lahey, M. (1978). Language development and language disorders. New York: John Wiley \& Sons.

3. Chomsky, N. (1957) Syntactic structures, Mouton, The Hague.

4. Chomsky, N. \& Halle, M. (1965). Some controversial questions in phonological theory. Journal of Linguistics, 1 (2) : 97138.

5. Darley, F. L. et. al (1975). Motor Speech Disorders. Philadelphia: W.B. Saunders Company.

6. Dodd, B. (1974). The acquisition of phonological skills in normal, severely subnormal and deaf children, University of London, Doct. Diss.

7. Dodd, B. (1976). The phonological systems of deaf children. Journal Speech \& Hearing Disorders, 41(2), 185-197.

8. Edwards, J., Fourakis, M., Beckman, M.E. \& Fox, R.A. (1999). Characterizing knowledge deficits in phonological disorders. Journal of Speech, Language, and Hearing Research, 42, 169-186.

9. Edwards, M.L., \& Shriberg, L.D. (1983). Phonology: Applications in communicative disorders. San Diego: College-Hill Press. 
10. Goswami, G. (1982). Structure of Assamese. A publication of Gauhati University.

11. Grwburg, M., \& Rvachew, S. (2006). Phonological awareness intervention for children with speech sound disorders. American Journal of Speech-Language Pathology, 15, 165-176.

12. Hegde, M.N. (1994). A course book on language disorders in children. San Diego, Singular publishing group.

13. Hegde, M.N. \& Davis, D. (1995). Clinical methods and practicum in speech and language pathology. San Diego, Singular publishing group.

14. Hegde, M.N. (1996). A pocketguide to treatment procedures in speech and language pathology. San Diego, Singular publishing group. 